\title{
Die strategiese funksie van die Christus-himne in Kolossense 1:13-20
}

\author{
Francois P. Viljoen \\ Skool vir Bybelwetenskappe en Bybeltale \\ Potchefstroomse Universiteit vir $\mathrm{CHO}$ \\ POTCHEFSTROOM \\ E-pos: sbbfpv@puknet.puk.ac.za \\ Abstract
}

The strategic function of the Christ hymn in Colossians 1:13-20

The author of the letter to the Colossians positions and utilizes a Christ hymn in a strategic and functional way in his writing. This hymn forms a pivotal point in his letter and mentions the crucial theological issues that are at stake. The Colossians were threatened by false teachings according to which they were subject to different powers. Christ is, however, exalted and praised as superior to all these powers. As such the hymn lays the basis for the argumentation of the letter. The hymn describes the significance of Christ: He is the mediator of creation, the reconciler of the world, the head of the church. Dependence upon Christ sets one free from ties to all the proposed powers. The author assumes that his readers would also associate with the contents of the hymn regarding the supremacy of Christ. If so, the author actually wins his argument. He, therefore, does not need to convince them of his theological viewpoint anew, but can immediately continue warning them about the dangers of false teachings threatening their community.

\section{Inleiding}

Die oorwegende navorsingstendens is om Kolossense 1:15-20 te beskou as 'n reeds bestaande lied wat deur die outeur van die brief opgeneem en redaksioneel aangepas is (vgl. Barkhuizen, 1985:20). Nie almal stem egter ooreen oor die omvang van die himne nie. Die meeste navorsers beskou Kolossense 1:15-20 as die himne. Veral die ouer werke (bv. Norden, 1913:250 e.v.) beskou Kolossense 1:12-14 ook as deel van die himne. Ander, byvoorbeeld Lohmeyer [1930] (1964:41) beskou 1:13-20 as die himne. 
Ekself gaan van die vertrekpunt uit dat die enigste vorm waarin die himne aan ons bekend is, is soos wat dit te vind is in Kolossense 1:1520. Die fokus van hierdie artikel is daarom nie om die sogenaamde oorspronklike himne te probeer rekonstrueer nie, hoewel die waarskynlike oorsprong van sodanige himne lig kan werp op die funksie van die lied. Die himne, sy posisie en formaat in die Kolossense as sodanig word ondersoek.

Die sentrale teoretiese argument is dat die skrywer van die brief die himne strategies in sy argumentasie van die brief gebruik. Die doel van die artikel is om die strategiese funksie van die himne binne die brief te bepaal en dan aan te toon hoe die skrywer teologiese perspektiewe uit die himne gebruik as basis vir die argumentasie in sy brief.

Die metode wat gevolg word om die stategiese funksie van die himne te bepaal, is om die die waarskynlike agtergrond van die himne te identifiseer en dan te bepaal hoe die himne binne die epistolêre struktuur van Kolossense inpas. 'n Analise van die himne as sodanig word vervolgens gemaak om teologiese perspektiewe daarin te identifiseer en aan te toon hoe die outeur van Kolossense hierdie konsepte funksioneel in die argumentasie van sy brief as geheel aanwend.

\section{Agtergrond van die himne}

Uitgaande van die veronderstelling dat 'n bestaande himne in Kolossense geïnkorporeer is, word die agtergrond, outeurskap en struktuur van die oorspronklike himne op talle maniere deur navorsers gerekonstrueer. Die aannames gaan uit van die veronderstelling dat konsepte in die himne nie de novo deur die outeur of selfs deur Christene geskep is nie. Die verklaring van die himne word grootliks bepaal deur die historiese en religieuse oorsprong van die himne te rekonstrueer en waarskynlike redaksionele wysigings van die skrywer van die Kolossensebrief te ontleed en op grond daarvan te verklaar (Sanders, 1971: ix).

Verskeie standpunte word gehuldig oor wat die agtergrond van die himne kon wees ${ }^{1}$. Die volgende is van die mees prominente beskouings.

- Ridderbos (1960:151) beskou die himne as 'n eie komposisie van die outeur waar die Seun van God as die tweede Adam besing word, omdat God deur Hom 'n nuwe begin gemaak het.

1 Vergelyk Hendriksen (1962:67-68) en Roberts (1988a:91) vir 'n omvattende oorsig van die verskillende standpunte. 
- Volgens Käsemann (1965:36-39) het die himne 'n Gnostiese oorsprong en is dit vir die Christelike doopliturgie oorgeneem. Hy is

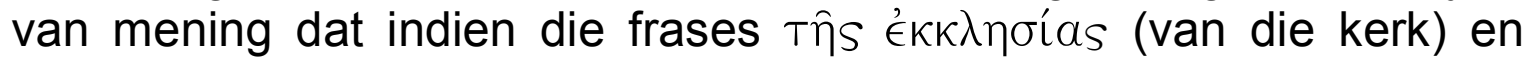

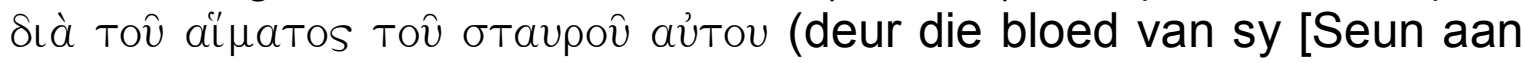
die] kruis) as latere redaksionele toevoegings van die Christelike outeur gesien word, daar niks spesifiek Christeliks in die himne is nie.

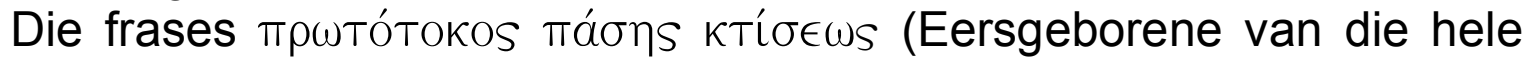
skepping) in die himne is volgens hom tipies van die Gnostiek. As aanvaar word dat die brief aan die Kolossense uit die eerste eeu dateer, is hierdie afleiding egter onwaarskynlik, aangesien so 'n interpretasie anachronisties sou wees. Die Gnostiek het eers in die tweede en derde eeu tot ontplooiing gekom - soos wat blyk uit Gnostiese geskrifte wat uit dié later tyd dateer.

- Lohmeyer (1964:43-47) is weer van mening dat die godsdienshistoriese agtergrond van die himne te vind is in die Joodse tradisies rondom die Groot Versoendag van die Ou Testament. Lohmeyer gebruik die konsep van die versoening aan die einde van die himne

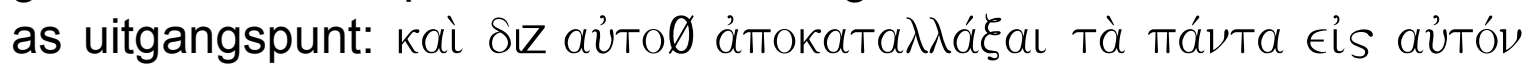
(en deur Hom het Hy alles met Homself versoen).

- Kehl (1967:52-161), Lohse (1968:84 e.v.), Schweizer (1976:53vv) en Pokorny (1987:52-57) soek die agtergrond van die himne in die Hellenistiese Judaïsme. Die lied sou dan aangepas wees om uitdrukking te gee aan 'n vroeg-Christelike belydenis van Christus. Die

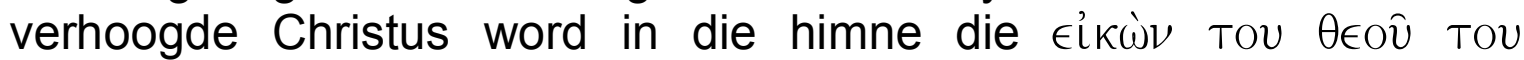

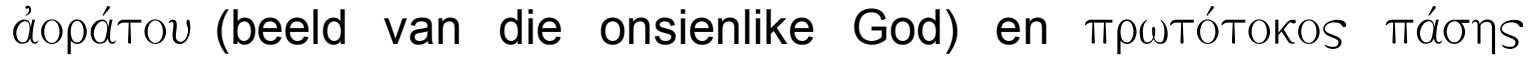
$\kappa T i ́ \sigma \epsilon \omega S$ (Eersgeborene van die hele skepping) genoem. Dit stem volgens hulle ooreen met die karakteriserings van Wysheid deur die Hellenistiese sinagoges. Wysheid is geprys as synde geskep voor alle dinge, as die eersgeborene van God (Helyer, 1994:241; Lamp, 1998: 53).

Om sin te maak uit al die moontlikhede, is die volgende vraag van Martin (1983:132) rigtinggewend: "What was the 'catalyst' that led to the creation of new forms of hymns in the New Testament period, specifically the hymn directed to the praise of Jesus Christ as exalted Lord and ruler of creation?" Die antwoord is heel waarskynlik geleë in die bedreiging van dwaalleer (vgl. Martin, 1983:134). As belangrikste kenmerke van die dwaalleer noem Martin (1983:134) die volgende:

- die ontkenning van Christus as Here en die enigste Middelaar tussen God en die wêreld; 
- 'n verswakte morele lewensuitkyk wat Christene onverskillig maak teenoor sondige begeertes; en

- onsekerheid oor die sin van die lewe, omdat die hemelliggame en afgode steeds heers en tevrede gestel moet word.

Hierdie kenmerke berus almal op die beginsel dat daar 'n ruimte tussen God en die wêreld bestaan wat gevul is met 'n reeks bose magte. Wat dus nodig is, is gemeenskap met God wat sy volgelinge kon bevry uit die verknegting aan hierdie magte. So ' $n$ God is gehuldig as Here en Verlosser.

Dit is teen hierdie agtergrond dat die himne in die Christelike kerk vorm aangeneem het (Snyman, 1989:46). Dit was 'n lofprysing op Christus, eers oor wat Hy voor die skepping gedoen het, en dan oor sy koms na die wêreld, en uiteindelik oor sy heerskappy oor alle magte.

Dit is waarskynlik teen hierdie agtergrond dat ook die himne in Kolossense 1:15-20 vorm aangeneem het. Dit is daarom ook gepas dat dié himne in hierdie brief ingevoeg is. Paulus ${ }^{2}$ het die brief geskryf om 'n dwaalleer in Kolosse te bestry. 'n Ernstige gevaar van dié dwaling was dat hulle blykbaar diegene wat nie hulle beskouing gedeel het nie, veroordeel het, omdat hulle dan nie met God versoen sou wees nie (Sumney, 1993:379).

Dit is duidelik dat die dwaalleraars die genoegsaamheid van die versoening wat Christus bewerk het, bevraagteken het (Van Broekhoven, 1997:87). Die dwaalleraars het die versoening van die mens ook beskou as onderworpe aan magte, engele en materiële elemente (Kol. $2: 8,20)$. Die versoening tussen God en die mens is nie aan Christus toegeken nie en was "dependant rather upon their own success in mastering the rules and rituals of spiritual accent" (Van Broekhoven, 1997:88).

Vroeëre navorsers, onder andere Lightfoot ([1879] 1961:73-113) het die agtergrond van die dwaling in die Gnostiek gesoek. Die feit dat navorsers die ontwikkeling van die Gnostiek as latere tendens uit die

2 Tot en met die negentiende eeu is die outeurskap van Paulus ten opsigte van die Kolossensebrief algemeen aanvaar. Daar bestaan geen bewyse dat sy outeurskap ooit bevraagteken is tot voor dié tyd nie. Sedert 1820 het baie wetenskaplikes egter skepties geraak om te aanvaar dat Paulus die werklike outeur van Kolossense (en Efesiërs) is. Die teorie dat 'n Paulinis die brief saamgestel het, dit ten koste van homself aan Paulus toegeskryf het, sy aanspraak op apostoliese gesag vals is en dat die destydse kerk dit sonder enige voorbehoud as 'n brief van Paulus aanvaar het, is heelwat minder geloofwaardig as om eenvoudig te aanvaar dat Kolossense Paulus se eie werk is. 
tweede en derde eeu sien, maak so 'n interpretasie problematies. Die tendens is dat navorsers daarom wegbeweeg van die gnostiese interpretasie van die gegewens na die stel van 'n hoofsaaklik niegnostiese, maar wel sinkretistiese, Joodse agtergrond ter verklaring daarvan (o.a. Bandstra, 1974:339-343). Die aard van die rigting wat teengestaan word, word gesoek in die Joodse merkabah-mistiek wat sou aanspraak maak op mistieke hemelreise in hierdie liggaamlike bedeling (Roberts, 1988b:821). So 'n ervaring sou as vereiste gestel word om van kosmologiese kragte verlos te word (vgl. ook Vergeer \& Janse van Rensburg, 1994:3; Vergeer, 1995:413).

Teenoor hierdie dwaling het Paulus die himne gebruik om die kosmologiese middelaarskap van Christus te stel.

\section{Die plek van die himne binne die brief}

Die strategiese funksie van die himne blyk ook uit die spesifieke plasing daarvan binne die struktuur van die brief. Die analise van die struktuur van 'n dokument bevat noodwendig subjektiewe elemente. Die beginsels en teorie van die antieke epistolografie bied egter sekere elemente waarvolgens so 'n brief ontleed kan word (vgl. Du Toit, 1984:8-9; Malherbe, 1988). Hierdie elemente is gebruik in die volgende ontleding van die brief3:

Briefaanhef (Praescriptio): 1:1-2

Inleiding (Prooemium): 1:3-2:5

(Voorbereiding vir die vermaning teen die dwaling: God se heil en die gevaar van verleiding)

Verslag van Paulus se danksegging: 1:3-8

Verslag van Paulus se voorbidding: 1:9-12

Belydenis en Christushimne4: 1:13-20

Betekenis van die belydenis (en himne) vir die lesers: 1:21-23

Waarskuwing teen die agtergrond van die belydenis om nie verlei te word nie: 1:24-2:5

Briefliggaam (Corpus): 2:6-4:6

('n Lewenswandel in ooreenstemming met die belydenis (himne))

3 Vgl. ook die beredenering van die ontleding van die brief in Viljoen (1990:97 e.v.)

$4 \quad$ In aansluitig by Schnider en Steger (1987:44-45) en Pokorny (1987:30) beskou Botha (1989:66-69) Kolossense 1:13-23 as 'n onderdeel van die outeur se danksegging: "In die geval van die danksegging as geheel - en spesifiek die himne - het ons hier 'n pragtige voorbeeld van die gebruik van die epideiktiese genre". Hoewel die himne die inhoud van Paulus se danksegging kernagtig verwoord, bied dit egter nie as sodanig 'n verslag van sy danksegging nie. Hier word nie meer gebid nie, maar die geloofsoortuiging van die vroeë kerk word bely. 
Inleiding (Partitio): 2:6-8

Weerbaarmaking van die geadresseerdes teen die dwaalleer (Argumentatio): 2:9-23

In Christus het die gemeente die volle heil (Probatio): 2:9-15

Die gemeente het geen ander heilsleer nodig nie (Refutatio): 2:16-23

Oproep om op Christus gerig te wees (Peroratio): $3: 1-4$

Die aardse werklikheid van 'n opstandingslewe (Exhoratio): 3:5-4:6

Aflê van die ou lewe en opstanding van die nuwe: $3: 5-17$

Huistafels: $3: 18-4: 1$

Slotparanese: $4: 2-6$

\section{Briefslot: $4: 7-18$}

Reeds uit hierdie ontleding blyk die strategies funksie van die himne in die brief as geheel. $\mathrm{Na}$ sy gebruiklike verslag oor sy danksegging en voorbidding vir die gemeente, voeg Paulus eers die belydenis en himne in. Met hierdie ongewone byvoeging in die briefstruktuur stel Paulus in kern reeds die argument waarmee hy die dwaling in die gemeente weerlê. Met die himne berei hy die grond vir die vermaning wat dadelik in die corpus van die brief volg.

Himnes en digterlike gedeeltes maak gebruik van emotiewe krag. Benewens die intellektuele inhoud van die himne, bied dit ook 'n emotiewe basis vir die argument. Himnes is bedoel om gesing te word. Hoewel ons vandag nie toegang het tot die toonaard van hierdie lied nie, sou dit ook kon bydra tot die affektiewe waarde van die lied.

'n Nadere ondersoek van bogenoemde onderdele van die brief maak hierdie funksie van die himne nog duideliker.

\section{Aanloop tot die himne (Kol. 1:1-12)}

Kolossense 1:1-12, die gedeelte voor die himne, vorm die aanloop tot die himne. Reeds in hierdie gedeelte is daar duidelike aanduidings van die hoofsaak waaroor Paulus skryf. Hy doen moeite om sy lesers te oortuig om te bly by die evangelie wat aan hulle verkondig is. Hulle moet hulle nie laat verlei deur die dwaling wat begin posvat in hulle midde nie (Wolter, 1993:37). Paulus gryp in sy inleiding (prooemium) met die belydenis en himne reeds vooruit na die hoofsaak (corpus) van die brief (vgl. Roberts, 1988a:827 se beredering van hierdie oorgangtegniek van die skrywer). Met sy inleiding berei hy sy lesers voor vir die hoofsaak wat later aan die orde kom.

Die brief begin met 'n gebruiklike aanhef (praescriptio) waarin hy homself 
as skrywer identifiseer, meld wie die ontvangers van die brief is en hulle groet deur die seën van God vir hulle toe te sê (1:1-2). Paulus beskryf homself as 'n gesant wat sy volmag van Christus ontvang het. Hy het nie self besluit om Christus Jesus se boodskapper te wees nie. Hy is dit omdat God dit so wou hê. So laat hy die Kolossense van die begin af verstaan dat hulle moet luister na wat hy sê. Hy tree immers volgens die wil van God op - in teenstelling met die dwaalleraars in hulle midde. Hy noem ook vir Timoteus as medeskrywer wat saam met hom in diens van Christus Jesus staan. Hulle twee is saam betrokke by die belangrike boodskap wat hulle aan die broers in Kolosse moet oordra. Die ontvangers van die brief beskryf hy as broers in Christus wat aan God behoort en op Hom vertrou. In die seën wat Paulus aan hulle toesê, beklemtoon hy dat die Vader vir die ontvangers seën bewerk het. Dit is juis die genoegsaamheid van hierdie heil wat die dwaalleraars bevraagteken. Hierdie praescriptio het 'n belangrike funksie deurdat Paulus van meet af interne kohesie bewerk tussen hom en die lesers teenoor die dwaalleraars (Van Broekhoven, 1997:76).

Na die aanhef in 1:1-2 volg die inleiding (prooemium) van die brief in 1:323 waarin hierdie interne groepslojaliteit verder versterk word. In die eerste plek berig Paulus van sy danksegging aan God, omdat hy 'n goeie berig oor die lesers ontvang het $(1: 3-8)$. Hy is dankbaar dat hulle gelowig geword het, en dat hulle liefde openbaar teenoor alle gelowiges. Paulus plaas klem daarop dat diegene wat die evangelie aan hulle verkondig het, predikers van die waarheid is. Hierdie leer van die waarheid het die lesers hulle eie gemaak. Die evangelie hou vir elkeen wat dit glo, 'n heerlike hoop in. Vir elkeen wat op God vertrou, wag daar 'n nuwe toekoms by God. Hierdie heil word vir 'n gelowige soos 'n skat by God in die hemel bewaar. Paulus kontrasteer blykbaar die predikers van die waarheid met die predikers wat beroering bring (vgl. Hendricksen, 1962:50). Die dwaalleraars se nuwe leer trek dié heerlike hoop in twyfel. So poog hulle om die gemeente in Kolosse van die evangelie afvallig te maak.

Paulus volg die berig oor sy danksegging op met 'n berig oor hoe hy vir hulle voorbidding doen (1:9-12). Hierdie verslag van hom bestaan uit twee dele. In die eerste gedeelte (1:9-10a) vertel hy waarvoor hy gereeld vir hulle bid. Hierdeur toon Paulus dat die dwaling in hulle midde 'n ernstige probleem is, iets waaroor hy ernstig vir hulle bid. Hy bid dat hulle volledige kennis verkry van wat God se wil is en dat dit moet lei tot 'n lewenswandel wat die Here eer sal aandoen. Paulus oordeel dat sommige gemeentelede verwar is deur die dwaalleer, omdat hulle 'n gebrek aan kennis het. Hoewel hulle die evangelie gehoor het en gelowig geword het, besef hulle nog nie die volle implikasie daarvan nie. Daarom is daar ook 'n gebrek in hulle lewenswandel. Omdat Paulus 
spesifiek vir hierdie insig bid, kan hulle dit moeilik ignoreer wanneer hy dié insig later aan hulle verduidelik.

Die tweede deel van die verslag oor sy voorbidding (1:10b-12) beskryf vier kenmerke van so 'n lewe wat eer aan die Here sal bring:

- hulle moet 'n vrugbare lewe lei deur goeie werke te doen;

- hulle moet toeneem in die kennis van God;

- hulle moet krag ontvang om in alle omstandighede geduldig te volhard en bly te wees;

- hulle moet dankbaarheid teenoor die Vader betoon, omdat $\mathrm{Hy}$ genoeg gedoen het om hulle heil te verseker.

Hierdie bedes moet die gemeente moed gee en verseker dat die heil wat God bewerk het, voldoende is. So kan hulle die bedreiging in hulle midde die hoof bied. Wie die Vader vir sy heil dank, kan tog nie met vrese rondloop dat die heil wat Christus bewerk het, tekortskiet en hulle nog iets daarby nodig het nie.

O'Brien (1982:100-102) identifiseer vier funksies van danksegging wat ook in die Kolossense-danksegging voorkom:

- om die skrywer se pastorale en apostoliese besorgdheid oor die geadresseerdes te beskryf;

- om die hooftema van die brief aan te kondig;

- om die wesentlike punte van die vroeëre onderrig aan die geadresseerdes didakties in herinnering te roep; en

- om 'n voorafskaduwing te bied van die paranese wat later in die brief volg.

In sy geheel beskou, stimuleer Paulus met hierdie inleiding 'n sterk interne kohesie tussen hom (sy standpunt) en dié van sy lesers (Van Broekhoven, 1997:76-79). Paulus identifiseer hom met die groep en bewerk as sodanig 'n lojaliteit teenoor sy standpunt.

Dit is duidelik dat Paulus met hierdie aanloop tot die himne $(1: 1-12)$ sy lesers deeglik voorberei vir die hoofsaak van die brief wat na die himne in die corpus van die brief gaan volg. Deur hom te vereenselwig met sy sy lesers, verkry hy lojaliteit teenoor sy standpunt, teenoor dié van die dwaling.

Voor hy dan by die hoofsaak as sodanig kom, gebruik Paulus 'n belydenis $(1: 13-14)$ en die himne $(1: 15-20)$ om op strategiese wyse as basis te dien vir die corpus van die brief. 


\section{Belydenis en himne as basis vir die argument van die brief}

\subsection{Belydenisformule (Glaubensformel)}

Die himne word direk voorafgegaan met 'n tipiese belydenisformule in 1:13-14 (Stauffer, 1948:316). Stauffer (1948:214) wys daarop dat talle himnes die aard van 'n belydenis het en talle belydenisse die aard van 'n himne. Vandaar die noue koppeling tussen die belydenisformule en die himne.

Terminologie wat in verband met belydenisuitsprake in die Nuwe Testament gebruik word, is nie eendersluidend nie. Zimmerman (1968: 162-163; 169-172) onderskei tussen belydenisse (Bekenntnisse) wat liturgiese tradisiestof sou wees en formules (Glaubensformel). Die onderskeiding van Conzelmann (1955) sluit hierby aan. Hy onderskei tussen homologie en credo. ' $n$ Homologie is 'n kultiese akklamasie en proklamasie van die teenswoordige posisie en status van Jesus in die midde van die versamelde gemeente. As credo onderskei hy leerstof wat geglo word (regula fidei). Hahn sluit hom ook by hierdie hoofonderskeiding aan:

Neben dem 'Bekenntnis' im engeren Sinne der homologia mit seiner akklamatorischen Funktion steht im Neuen Testament die 'Glaubensformel'. Das Bekenntnis bezieht sich stets auf den erhöhten und lebendigen Herrn in seiner gegenwärtigen Stellung und Funktion: $\mathrm{Er}$ ist der Herr, der Christus, der Gottessohn: Die Glaubensformel redet primär in der Vergangenheit: Sie blickt zurück auf das was geschehen ist (Hahn, 1980:207).

Volgens hierdie onderskeid kan Kolossense 1:13-14 as 'n belydenisformule (Glaubensformel) beskou word. Dit handel oor die Vader wat deur sy Seun vir die gelowiges heil bewerk het:

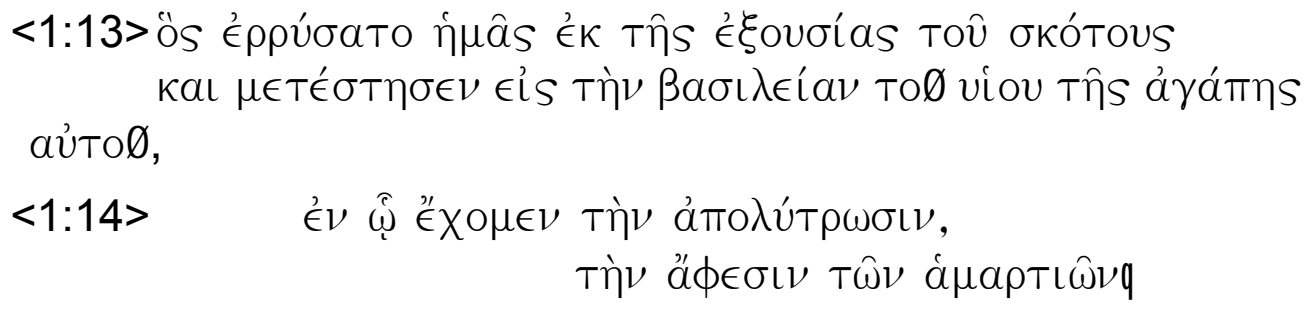

(Hy het ons uit die mag van die duisternis weggeruk en ons onder die heerskappy gestel van sy Seun wat Hy liefhet. Deur die Seun het ons die verlossing verkry, die vergewing van ons sondes) (1983 Afrikaanse Vertaling).

Hierdie belydenisformule bevat die spesifieke punt wat Paulus by sy lesers wil tuisbring: die beeld van twee opponerende wêrelde, die wêreld 
van God en die wêreld van die bose, tree hier op die voorgrond. Die mag van die duisternis staan teenoor die koninkryk van die lig. Die belydenisformule verwoord die heilshandeling van God (vers 13) en die heilservaring van die belyers (vers 14). Die heilshandeling van God is daarin geleë dat diegene wat eers in die mag van die bose was, gered is toe die Vader hulle oorgebring het na die wêreld van die lig en hulle onder die heerskappy van sy Seun gestel het. Hierdie bevryding bestaan uit die vergifnis van sonde. God het die verlossing bewerk deur die Seun. Die gelowige het deur sy verbondenheid aan die Seun, as heilservaring, deel aan die verlossing. Deur sy bloed, sterwe en oorwinning oor die dood, het $\mathrm{Hy}$ die gelowiges verteenwoordig deur hulle as 't ware by Hom in te trek.

\subsection{Himne (Bekenntnis)}

$\mathrm{Na}$ die belydenisformule (1:13-14) volg die himne (1:15-20). Volgens die onderskeid van Conzelmann (1955) en Hahn (1980:207) kan die himne as die Bekenntnis beskou word. Die onderskeiding tussen die Christologiese belydenis (Glaubensformel) en die himne (Bekenntnis) beskryf Hahn (1980:212) soos volg: "Wir stellten fest, dass die Glaubensformeln das christologische Bekenntnis im Sinn der Akklamation durch den Hinweiss auf das Heilshandelen Gottes in Christus begründen und explizieren". Die belydenisuitspraak in Kolossense 1:13-14 begrond en verduidelik dienooreenkomstig vooraf die betekenis van die himne as Bekenntnis wat in 1:15-20 volg. Saam met die belydenisformule vorm die himne daarom 'n lang inhoudryke belydenis (Roberts, 1988a:93; 1997b: $33)^{5}$.

Waar die belydenisformule die heilshandeling van God en heilservaring van die belyer verwoord, word die besondere status van die Seun van God in die himne (Bekenntnis) besing. Die himne fokus op wie en wat die Seun is. Vanweë sy besondere status is Hy die geskikte Heilmiddelaar om mense wat aan Hom verbonde is, in die verlossing te laat deel.

\subsubsection{Ontleding van die himne}

Om die treffende patroonmatigheid van die himne aan te toon, word dit by wyse van kola en kommata ontleed. Die kola en kommata word tussen hakies by elke reël genommer vir verwysing by die bespreking wat volg. 'n Eie vertaling in Afrikaans word tussen hakies bygevoeg. vind dit verstandiger om 1:13-14 en 1:15-20 in geheel as 'n stuk belydenis te benader. 


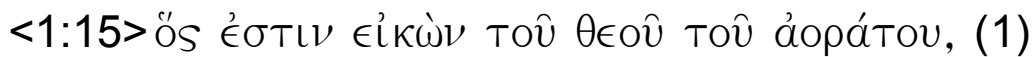

(Die Seun is die beeld van God, van God wat self nie gesien kan word nie.)

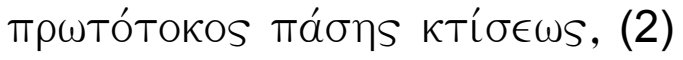

(Die Seun is die Eerste, verhewe bo die hele skepping (die Eersgeborene van die hele skepping)).

<1:16> ÖTL Èv aủT

(want God het deur (in) Hom alles (alle dinge) geskep)

Év Toîs oủpavoîs (2.1.1)

(wat in die hemel(e))

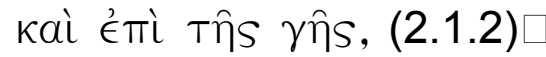

(en op die aarde (is))

Tà ópatà (2.1.3)

(die sienlike (dinge))

kaì tà ảópata, (2.1.4)

(en die onsienlike (dinge))

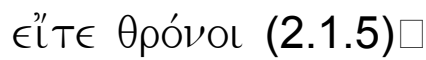

(hetsy trone)

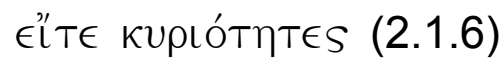

(of heerskappye)

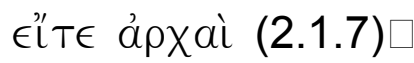

(of owerhede)

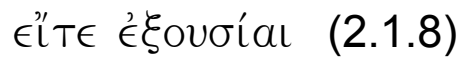

(of magte)

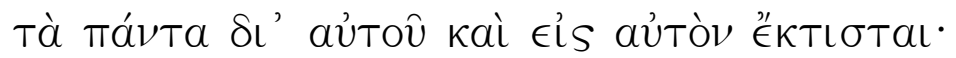

(Alle dinge is deur Hom en vir Hom geskep)

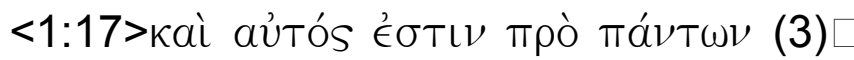

(en $\mathrm{Hy}$ is voor alle dinge (voor alles was $\mathrm{Hy}$ al daar))

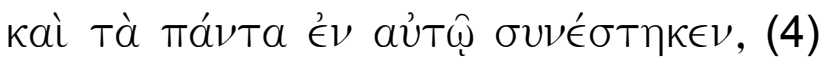

(en deur Hom het alle dinge tot stand gekom (bly alles in stand))

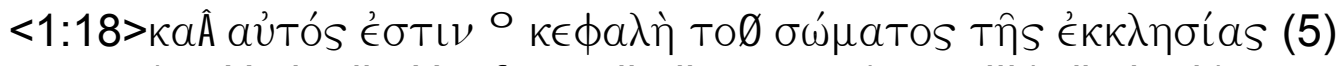

(en Hy is die Hoof van die liggaam, (naamlik) die kerk)

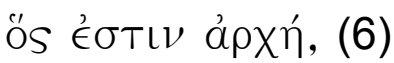

(Hy is die eerste (oorsprong daarvan))

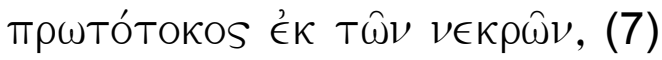

(die Een wat uit die dood opgestaan het (die Eersgeborene uit die dode)) 


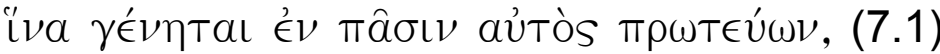

(sodat Hy die eerste plek in die heelal inneem)

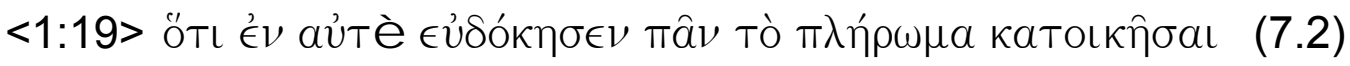

(want Hy (God) het besluit om met sy volle wese in Hom te woon)

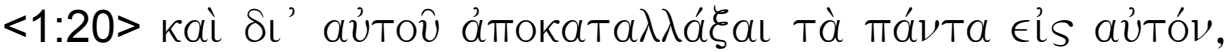

(en deur Hom alles met Homself te versoen)

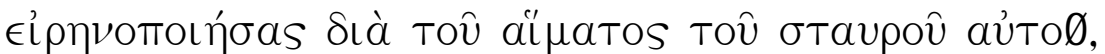

(deur die bloed van Hom (die Seun) aan die kruis het Hy vrede herstel)

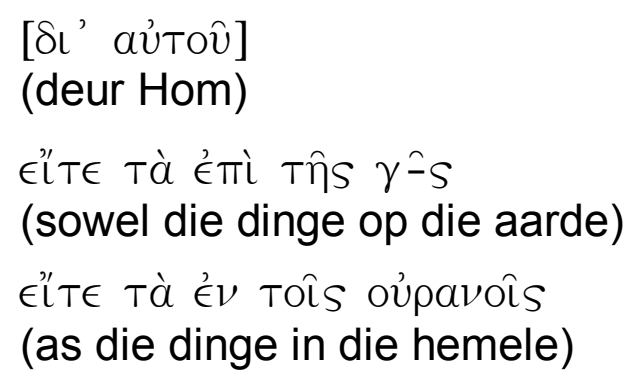

Die doel waarom Paulus die geloofsformule en himne juis hier in sy betoog geplaas het, is blykbaar om aan die begin van die brief, as ' $n$ soort argument by voorbaat, 'n oorgang te vorm tot die saak wat in die briefliggaam hoofsaaklik by wyse van waarskuwings en vermanings uitgewerk word. Wie persoonlik hierdie geloofsformule en himne as gesamentlike belydenis aanvaar, sal sodoende gehelp word teen die verwarring wat die dwaalleraars bring (vgl. Roberts, 1988b:91-96; 1997a:484).

Soos blyk uit die inhoud van die himne wat vervolgens bespreek word, is die argument van die brief, waardeur die gemeente teen die bedreiging gewaarsku word, as 't ware reeds gewen. As sodanig vorm die himne in 'n sekere sin die swaartepunt van die brief. In hoofsaak word die himne gebruik om te bely dat die Vader vir die gelowiges heil bewerk het deur hulle geloof in sy Seun. Die Vader het aan sy Seun 'n hoë status gegee, sodat $\mathrm{Hy}$ volkome kon kwalifiseer as die Heilsmiddelaar van elke gelowige. Hy is die Verlosser en Here.

Dit is moontlik om in hierdie paar verse nie minder nie as dertig parallelismes op verskillende vlakke en in totaal drie en veertig stylfigure te identifiseer (Botha, 1989:55). Dit is kenmerkend van 'n himne (Barkhuizen, 1985:20). As 'n mens in ag neem dat die himne ook bedoel was om gehoor te word, word die impak daarvan nog méér voor die hand liggend (vgl. Harvey, 1998:283 e.v.). Deur hierdie hoogs poëties gedronge teks stel Paulus die argument wat as basis dien vir sy hele brief. 


\subsubsection{Strofiese samestelling}

Daar bestaan talle standpunte oor die strofiese samestelling van die himne. Balchin (1985:78-79) toon in tabelvorm voorstelle van verskeie navorsers oor hoe die himne volgens hulle in twee, drie, vier of selfs vyf strofes verdeel behoort te word. Die oorwegende tendens is om die himne in twee of drie strofes te verdeel. Die twee-strofe-indeling berus hoofsaaklik op die volgende parallelismes:

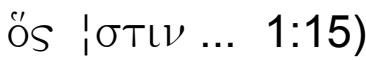

$$
\begin{aligned}
& \text { пршто́токоS ... (1:15) } \\
& \text { ÖTL ĖV aỦTબ̣ ... (1:16) } \\
& \text { Ös 9f } \\
& \text { пршто́токоS ... (1:18) (Eersgeborene) }
\end{aligned}
$$

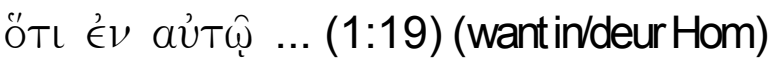

Op inhoudelike gronde word hierdie indeling ondersteun deurdat die eerste strofe oor die Seun se status ten opsigte van die skepping handel. Die tweede strofe handel oor die Seun se status ten opsigte van die herskepping.

Die belangrikste probleem met die tweedeling is dat $1: 18$ a tematies nie inpas by die eerste strofe nie. Op grond van die herhaling van $\kappa \alpha-(e n)$ in 1:17 en 18a lyk die drie-strofe-indeling meer aanvaarbaar. Dié verse kan beskou word as 'n middelstrofe of refrein by albei die verse (vgl. McCown, 1979:159).

Die himne val dus waarskynlik in twee strofes uiteen (kola 1 tot 2.2 en 6 tot 7.3) en word deur 'n refrein (kola 3-5) onderbreek. Elke strofe word deur die kenmerkende inleidingswoorde vir 'n himne ös É $\sigma T \iota \nu$ (Hy/wat is) ingelui (vgl. Fil. 2:6; 1 Tim. 3:16; 1 Pet. 2:22) (Stauffer, 1948:332). Treffende parallelle frases tussen die strofes en in die refrein bind die himne tot 'n eenheid saam (kola 1 en 6, 2 en 7, 2.1 en 7.2, en 3 en 5). In die refrein word die Seun agtereenvolgens as die Skepper, Onderhouer en Verlosser van alle dinge besing.

Anders as by talle vroeg-Christelike belydenisse is hier nie sprake van 'n chronologiese behandeling van die heilsgebeure nie. Ook die motiewe van lyding, hemelvaart en wederkoms ontbreek. Wat besonder opvallend is, is dat normale Christologiese motiewe van redding uit die dood en versoening met God hier in direkte verband met die skeppings- en onderhoudingmotief gemeld word (Lohse, 1968:86 e.v.; Pokorny, 1987:64). Christus is nie net herskeppingsmiddelaar nie, maar ook skeppingsmiddelaar. Hieruit blyk die sterk kosmologiese rol van Christus (Van Broekhoven, 1997:85).

\subsubsection{Inhoudelike bespreking van die himne}

'n Inhoudelike bespreking van die himne binne die onderskeie strofes bevestig die bevinding tot dusver dat Paulus die himne funksioneel aanwend in sy brief. 


\section{Strofe 1: Die Seun se status ten opsigte van die skepping}

In 1:15a (kolon 1) word die Seun se status gedefinieer in terme van sy verhouding met God. Die besondere verhouding van Christus met God is tipies van die Christelike himnes van die vroeë kerk (Martin, 1983:135).

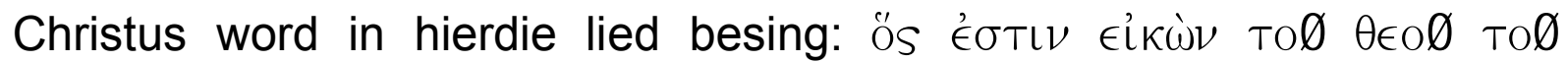
àора́тоu ((Hy) wat die beeld van die onsienlike God is). Die himne begin met dié woorde by wyse van 'n paradoksale stelling, wat dadelik die leser se aandag trek. Hoe is dit moontlik dat iets wat nie gesien kan word nie, afgebeeld word? Die gedagte van ' $n$ beeld van ' $n$ god was vir die mense in die tyd van Paulus hoegenaamd nie 'n vreemde gedagte nie. Hulle het hordes beelde van hulle gode gehad en die beelde aanbid. Van die God van die Ou Testament mog egter nie beelde gemaak word nie (Eks. 20:4-6). Dit kon ook nie, want Hy is die onsienlike. Maar dié God het Hom op 'n wonderlike manier in sy geliefde Seun bekend gemaak (vgl. Martin, 1972:45). In die Persoon en optrede van die Seun word God die Vader sigbaar. Hierdie verhouding tussen die Vader en die Seun bepaal die hoë status van die Seun.

Die status van die Seun in terme van sy verhouding tot die skepping word in vers 15b-16 verder omskryf (Roberts, 1997a:481). Hy word in die

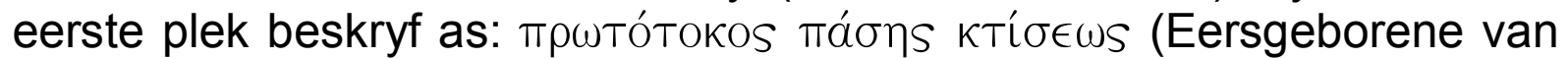
die hele skepping) (kolon 2). $\square \square$ Treffende assonansie (herhaling van die "o" klank) en alliterasie (herhaling van die "p"-, "t"-, en "s"-klanke) kom in

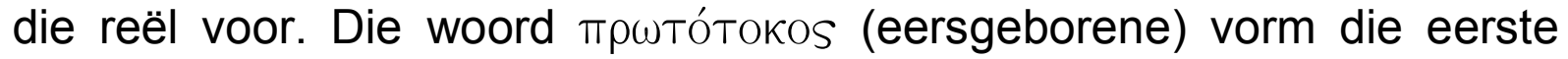
deel van 'n diafoor wat later in 1:18 (tweede strofe, kolon 7) herhaal word met ' $n$ ander betekenis. пршто́токоS dui in 1:15 daarop dat die Seun bestaan het voor die skepping ontstaan het (Ridderbos, 1960:138). Dit dui ook daarop dat Hy van ' $n$ hoër orde is as die skepping. Sy preeksistensie van die skepping word besing.

Hierna (kommata 2.1.1-2.1.3 in vers 16) volg die rede waarom Hy die eersgeborene is:

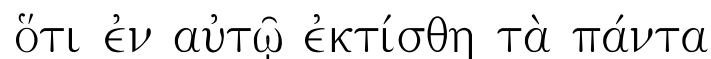

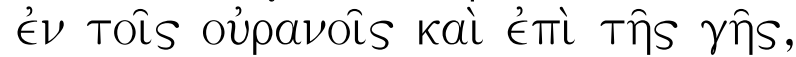

Tà ópatà kaì tà áópata,

(Want deur Hom is alle dinge geskape, die dinge in die hemele en op die aarde, die sigbare en onsigbare dinge.)

Treffende stylfigure kom in hierdie drie reëls voor. Die "ta"-klanke in Tà ópatà kaì tà áópata is 'n vorm van alliterasie. God het alle sigbare en onsigbare dinge deur middel van sy Seun geskep. Hy het ook alle dinge vir sy Seun geskep. Hierdie rede moet in verband met 1:13 verstaan word, waar staan dat die Seun as Koning heerskappy voer (Uitman, 1972:28). God het die heelal geskep vir sy Seun om oor te 
regeer. Sy Seun se aandeel aan die skepping word besing. Hy is nie deel van die maaksel nie, maar is die Maker. Alle geskape dinge is daarom ondergeskik aan Hom.

Paulus noem vier gesagsinstansies (kommata 2.1.5-2.1.8) om te beklemtoon dat ook hulle deur en vir die Seun geskep is:

Elı

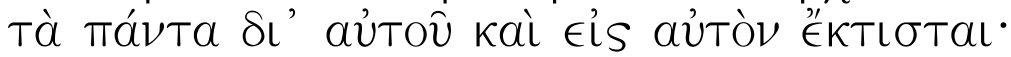

(sowel trone as heerskappye as owerhede as magte, al dié dinge is deur Hom en tot Hom geskape).

Die tema van "magte" word aanhoudend herhaal met die gebruik van 'n anaforiese stylfiguur (herhaling van $\epsilon$ lt $T \in$ (sowel as).) Baie navorsers is van mening dat hierdie reëls 'n redaksionele byvoeging deur die outeur van die brief is (vgl. Balchin, 1985:79, Van Broekhoven, 1997:85). Die herhaling van die tema van "magte" versterk die argument dat die himne op 'n besondere manier die kerntema van die brief aankondig, naamlik Christus se heerskappy oor alle magte (Helyer, 1994:246). Ook vorm

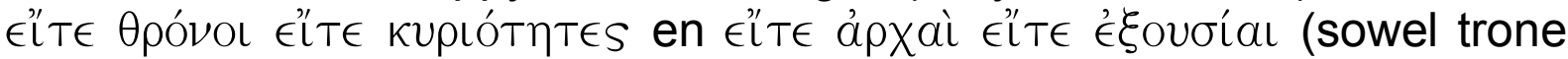
en heerskappye as owerhede en magte) 'n chiasme ${ }^{6}$. Hierdie magsbeskrywings as geheel staan ook weer parallel ten opsigte van die

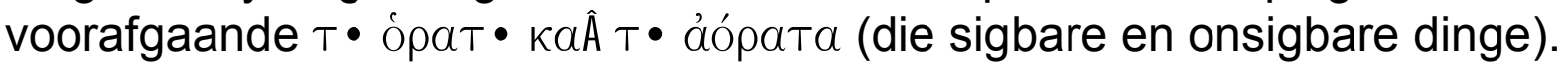

Dit is nie maklik om vas te stel wat presies met hierdie magsinstansies bedoel word nie (vgl. Viljoen, 1986:2). Wat wel uit die gedagtegang van die brief duidelik is, is dat sommige mense in Kolosse beangs was dat sommige van hierdie magte so 'n invloed op hulle kon uitoefen, dat hulle heil onseker sou wees. Paulus haal egter hierdie himne aan waaruit dit duidelik blyk dat die Seun bo enige magte staan, sienlik of onsienlik, aards of bo-aards, persoonlik of onpersoonlik. God het ook hierdie magte deur en vir sy Seun geskape. Alleen 'n lewende kosmiese Christus wat tegelyk die Skepper van die wêreld is, kon die godsdienstige kommer van die dwaling in Kolosse oorkom (Käsemann, 1965:50). Die gelowige is nie meer onder beheer van kosmologiese kragte nie, maar is slegs aan die Seun onderworpe.

\section{Refrein}

6 Bammel (1961:90-92) identifiseer die chiasme in dié reëls en lees hierdie chiasme parallel met tà ópatà kà tà ảópata (die sigbare en onsigbare dinge) in die voorafgaande reëls. Daarvolgens interpreteer hy trone ( $\theta \rho o ́ v o \iota)$ en owerhede $(\dot{a} \rho x a-)$

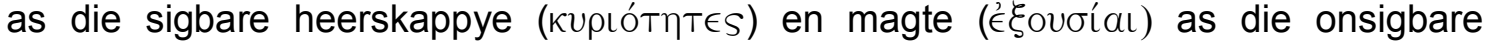
gesagsfigure of magte. Vergelyk ook Viljoen (1986) se beredenering van die onderskeid. 
Kola 3 tot 5 (vers 17-18a) vorm waarskynlik die refrein wat by elk van die strofes pas:

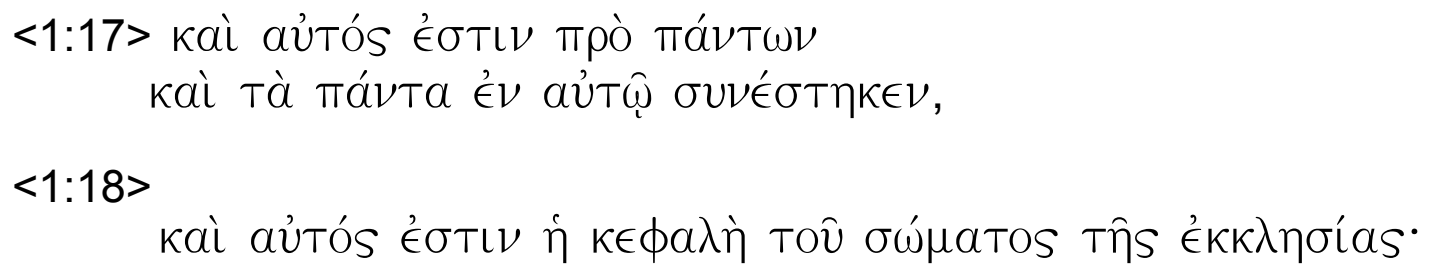

((En) voor alles was Hy al daar, en deur Hom bly alles in stand. (En)

$\mathrm{Hy}$ is die Hoof van die liggaam, van die kerk.)

Elke kolon van die refrein word met die woord $\kappa \alpha \neg($ en) ingelui, wat op 'n

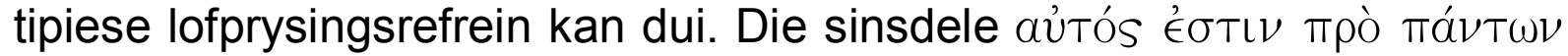

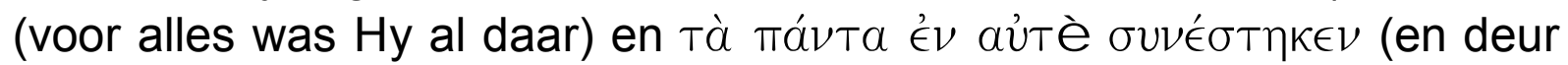
Hom bly alles in stand) vorm 'n chiasme. Ook vorm die frases aủTós

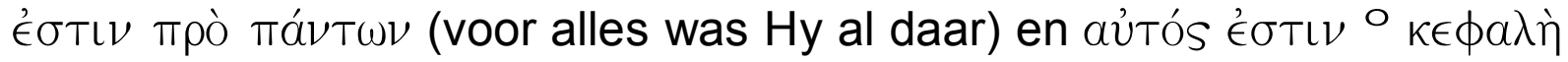

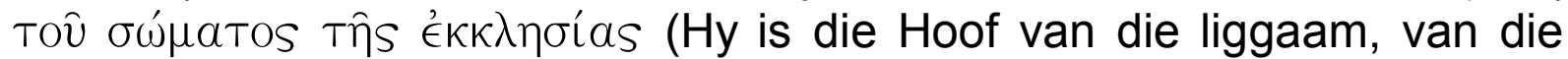
kerk)'n semantiese parallelisme. Kolon 3 (vers 17a) verwys terug na die feit dat die Seun die eersgeborene van die skepping is (strofe 1). Hiermee besing die gelowiges die sekerheid dat die Seun van voor alle tye af by die Vader was. Kolon 4 (vers 17b) bewerk die oorgang na kolon 5 (vers 18a) waarin die Seun se verhouding tot die Kerk beskryf word. Kolon 4 het betrekking op die Seun se verhouding tot die skepping (kolon 3 en die eerste strofe), maar ook op sy verhouding met die kerk (kolon 5 en die tweede strofe) (Ridderbos, 1960:139).

Hierdie kolon besing die Seun se voorrang bo alles wat bestaan, in die skepping (strofe 1) en in die herskepping (strofe 2). Hy gee aan alle geskape dinge hul plek en sorg dat elke ding in samehang met alle ander dinge bestaan en funksioneer. Dit is die resultaat van die Seun se bewind oor alle geskape dinge. Deur gebruik te maak van 'n metafoor impliseer kolon 5 dat die Seun die Hoof is van die kerk $\int \kappa \in \phi a \lambda$ "

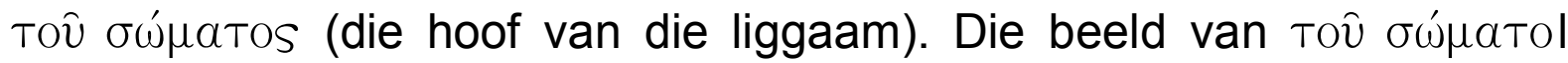
(die liggaam) verwys metonimies na die kerk. Die uitdrukking $\dot{\eta} \kappa \in \phi a \lambda$ "

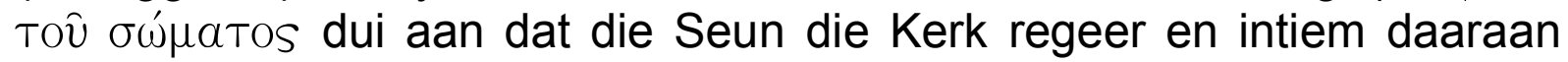
verbonde is. Christene is by Christus ingelyf. Wat met Hom gebeur het, het met hulle gebeur. So het hulle saam met Hom uit die dood opgestaan. Tussen die Seun en die kerk is daar 'n intimiteit wat tussen Hom en die skepping afwesig is (Martin, 1972:47).

Strofe 2: Die Seun se status ten opsigte van die herskepping

Die tweede strofe (vers 18b-20) beskryf die status van die Seun in terme van sy verhouding met die kerk.

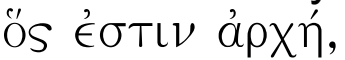




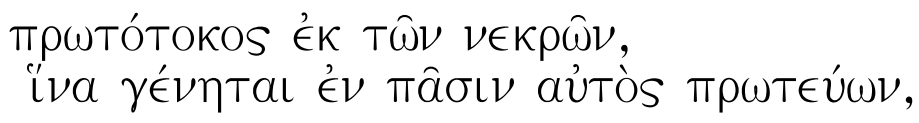

( $\mathrm{Hy}$ is die Eerste, die Een wat uit die dood opgestaan het, sodat Hy die eerste plek in die heelal inneem.)

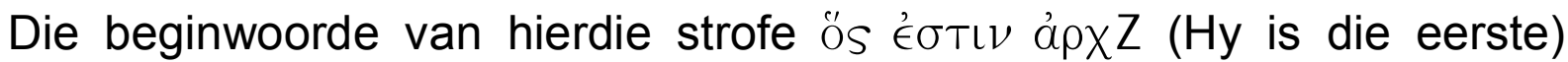
(kolon 6) staan parallel ten opsigte van kolon 1 , die beginwoorde van die

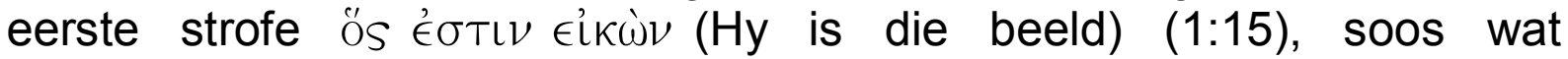
пршто́токоS (eersgeborene) in kolon 7 diafories ook parallel staan ten opsigte van dieselfde woorde in kolon 2 (1:15). Die Seun is die oorsprong ook van die nuwe lewe (18b), omdat Hy deur sy opstanding die dood oorwin het (18c) (Ridderbos, 1960:145). Hy is die eerste wat uit die dood opgestaan het (18c) en het daarom die hoogste rang bo almal.

In vers 19-20 vind ons die rede waarom die Seun die besondere status in die kerk moes beklee.

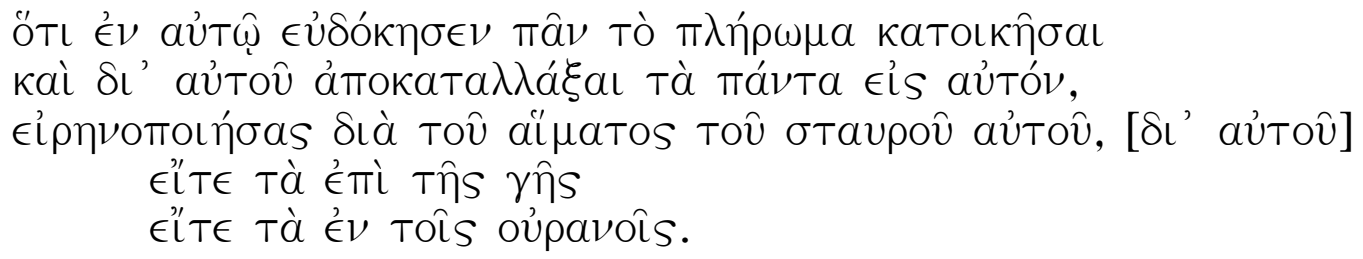

(God het besluit om met sy volle wese in Hom te woon en om deur Hom alles met Homself te versoen. Deur die bloed van die Seun aan die kruis het Hy die vrede herstel, deur Hom het Hy alles op die aarde en in die hemel met Homself versoen.)

Die een rede vir die Seun se status is dat dit God behaag het dat sy volheid in die Seun sou woon (vers 19). Die woorde ÖTı ÉV aủTË ... (want in Hom) in die vers staan parallel met dieselfde woorde in die eerste strofe (1:16). Die Seun van God dra in Homself die volle wese van God en is daarom self God. Juis daarom kan 'n mens nie anders as om die hoë status van die Seun te bely nie (Martin, 1972:47). Die ander rede vir die Seun se hoë status in die kerk is dat God gekies het om deur Hom alle dinge met Hom te versoen (vers 20). Dit het Hy gedoen deur sy bloed aan die kruis. Hierdie feit word beklemtoon deurdat die woorde

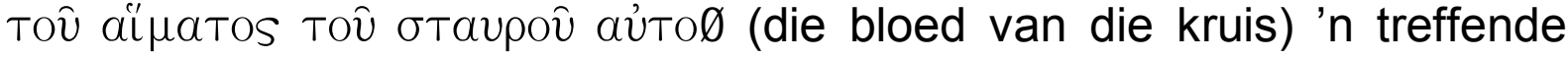
assonansie vorm deur die herhaling van "oe"-klanke. Die wêreld wat Hy met Homself versoen het, word in die himne in 'n chiastiese styl beskryf: dié op die aarde en ook dié bo die aarde. Hierdie beskrywing verwys na die hele skepping wat teen God in opstand gekom het. Deur die sondeval van die mens het alles op aarde hulle teen God verset. Die geskape wêreld verwys ook na die ruimte bo die aarde wat gevul is met magte en kragte wat teen God in opstand gekom het. Tussen God en die geskape wêreld het 'n stryd gewoed. God het egter ingegryp en die opstandige wêreld met Hom versoen. Dit het Hy gedoen deur die bloed 
van sy Seun. Die Seun het Homself aan die kruis geoffer vir die sonde wat die oorsaak was van die stryd, opstand en vyandskap. Hierdie middelaarswerk word as klimaks beskryf en dit verseker die hoë status van die Seun.

\subsection{Bevinding}

Die kosmologiese rol wat aan Christus in hierdie lied toegeken word, is van besondere belang. Die lied begin met ' $n$ verwysing na sy preeksistensie, sy verhouding tot God voor die skepping, en na sy aandeel aan die skepping. Die kosmologiese rol van Christus is tweedens belangrik, omdat Hy na sy verhoging beheer uitoefen oor alle kosmiese magte. Hierdie perspektief is wesenlik deel van Paulus se argument in die hele brief.

Paulus het dus 'n kunstig gekonstureerde himne gebruik om te beklemtoon dat Christus se heilswerk volkome en genoegsaam is. Vanweë die himne se emotiewe waarde en hoogs poëtiese styl behoort dit 'n besondere impak op die leser se hart en verstand te hê. Deur die gebruik van stylfigure word wesenlike teologiese motiewe beklemtoon. Sodoende word dit duidelik dat bo en behalwe die heil wat deur Christus tot stand gebring is, niks meer nodig is om die mens met God te versoen nie. Wie aan Christus verbonde is, het niks anders nodig om in vrede met God te lewe nie.

Paulus het hierdie himne, gekoppel aan die inleidende belydenis, juis hier in sy brief geplaas. Dit help om die kern van sy boodskap oor te dra. Grondslae van die geloof, juis van dié waaroor twyfel ontstaan het, word in die himne verwoord. Dit help lesers om soos hy te dink. Die himne dien immers as 'n gemeenskaplike belydenis, 'n geloofsoortuiging wat die lesers met die skrywer deel. As hulle met sy belydenis en himne saamstem, is die argument in wese al gewen. Daarom behoort die lesers ontvanklik te wees vir die waarskuwings en vermanings wat in die corpus van die brief volg.

Die funksie van versekering staan voorop. Gemeentelede wat begin twyfel het of Christus genoeg is om te verseker dat hulle God se heil sal beleef, word deur hierdie belydenis en himne herinner aan geloofswaarhede wat hulle met ander gelowiges deel. 'n Besef van die hoë status van die Seun bo die ganse skepping en die kerk laat alle twyfel verdwyn oor die beweerde tekort in die verlossing wat God deur sy Seun bewerk het. So word die gelowiges ook bemagtig om die dwaalleraars te konfronteer. Hulle kan met oortuiging teen die bedreiging veg. Hulle is immers aan die kant van die lig. Hulle staan onder die aanvoering van die Seun as Koning. Hy is hulle Hoof wat verhewe is bo enige mag in die skepping - hoe invloedryk ook al.

Paulus gebruik hierdie himne dus strategies in die opbou en gedagte- 
gang van sy brief. Deur die lied op hierdie uiters belangrike plek in die brief te gebruik, funksioneer dit as ' $n$ kragtige middel om die waardes wat by wyse van die lied deur die afsender en geadresseerdes gedeel word, te herbevestig. Dit blyk uit die verdere argument wat op die basis van die himne in die corpus van die brief gevoer word.

\section{Oorgang na die corpus gebaseer op die himne}

Die himne vorm die spits van Paulus se oorgang na die res van die brief (Roberts, 1997a:484). Met die belydenis en himne wat Paulus, as skrywer, en die Kolossense, as lesers, gemeenskaplik aanvaar, is die basis gelê vir die verdere ontplooiing van Paulus se brief. Die basis is dat die heilswerk wat God in Christus bewerk het, volkome genoegsaam is. Op grond hiervan bewerk hy met die volgende bykomende elemente die verdere oorgang na die corpus van die brief:

- die betekenis van die belydenis (himne) vir die jong Christene (1:2123) en

- die waarskuwing, teen die agtergrond van die die belydenis (himne), om nie verlei te word nie $(1: 24-2: 5)$

Die belydenis en himne (1:13-20) word in 1:21-23 opgevolg deur 'n verduideliking en toepassing van die belydenis en himne. In hierdie verse volg 'n verduideliking om die lesers goed te laat begryp wat dit beteken as hulle die belydenis en himne as hulle eie aanvaar het. In dié gedeelte kontrasteer die skrywer die toestand van die lesers vóór hulle versoening met God (vers 21) met dié daarna. Vroeër was hulle vyande van God. God het hulle egter met Hom versoen en die vyandskap in vrede verander. Dit het Hy gedoen deur die bloed van sy Seun. Daarom is hulle heilig, sonder smet en onberispelik voor God. So pas Paulus nou die inhoud van die belydenis en himne op die lesers toe.

Maar tog is daar 'n probleem. Daarom volg Paulus hierdie verduideliking op met 'n voorwaarde (23a). Hierdie voorwaarde kan eerder as 'n konsekwensie verstaan word vir diegene wat werklik die voorafgaande belydenis en himne as hulle eie aanvaar. As hulle dus wel die belydenis en himne as hulle eie aanvaar, sal hulle vanselfsprekend aan die voorwaarde voldoen. Hulle sal dan in die geloof bly en hulle nie laat losruk van die hoop wat die evangelie in hulle wek nie. Hierdie verduideliking en voorwaarde moet gelees word in die lig van die twyfel wat by sommige gelowiges in Kolosse ontstaan het of die heilswerk van Christus werklik genoeg is om hulle te red. Paulus beroep hom op die inhoud van die belydenis en himne om die lesers te waarsku om hulle nie te laat wegruk van hierdie sekerheid van die evangelie en sodoende sonder hoop gelaat te word nie. Hy wil hulle verseker dat die inhoud van die belydenis 
en himne ook op die lesers van toepassing is. Hulle het volledig deel in die heil wat God in Christus bewerk het.

Die toegevoegde verduideliking in 1:21-23 oor die betekenis vir die belydenis vir die ontvangers word gevolg deur 'n oorgangsparagraaf in $1: 24-2: 5$. As uitdrukkings van 'n persoonlike selfbekendstelling en 'n "leser moet weet"-gedeelte, het dit die funksie om die lesers ontvanklik te maak vir die boodskap wat volg.

\section{Corpus van die brief}

$\mathrm{Na}$ die oorgang volg die corpus van die brief, deur

- die gemeente daaraan te herinner dat hulle in Christus reeds die volle heil het (2:6-15);

- hulle te waarsku teen die standpunt van die dwaalleraars asof ander heil nodig is $(2: 16-23)$;

- die gemeente op te roep om hulle hart en gedagtes op Christus te rig (3:1-4); en

- die gemeente aan te moedig om in alle omstandighede 'n opstandingslewe te ly te midde van 'n heidense omgewing (3:5-4:6).

Dit is opvallend dat Paulus sy briefliggaam in 2:6 van meet af met 'n vermaning begin (Roberts, 1991:296; 1997a:494). Terwyl die corpus in sy ander briewe gewoonlik eers met 'n positiewe uiteensetting van die heil begin (vgl. Du Toit, 1984:11), beskou hy hierdie uiteensetting klaarblyklik as reeds afgehandel en die argument reeds gewen by wyse van die teologiese perspektiewe van die voorafgaande belydenis en himne. Al wat oorbly, is om die lesers teen die dwaalleer te waarsku en te vermaan om in die lig van die voorafgaande belydenis en himne reg te lewe en nie aan die eise van die ontwikkelende dwaalleer toe te gee nie.

In die lig hiervan word in die hoofdeel telkens na die teologiese perspektiewe van die belydenis en himne verwys sonder verdere argumentasie. Deurdat die gelowiges Christus deur hulle belydenis aangeneem het, het hulle oorgegaan na 'n nuwe staat van lewe (2:6-7). Hulle lewenswandel word bepaal deur hulle belydenis dat Christus wesens-een met God is en as kosmokrator oor alle magte heers. Deur Hom het hulle reeds die volle heil ontvang (vgl. 2:9-10; $2: 20 ; 3: 1 ; 3: 13$; $4: 1)$. Die bose magte hou vir hulle geen bedreiging meer in nie. 


\section{Gevolgtrekking}

Die belydenisformule (Glaubensformeln) en himne (Bekenntnis) word strategies funksioneel gebruik ter wille van die briefkommunikasie. In die eerste plek toon dit die belangrike sake waaraan Paulus wil aandag skenk. In die tweede plek lê dit ook die grondslag vir die argument wat hy wil voer. Met die himne word die argument as 't ware gewen. Die kosmologiese rol van Christus word duidelik in die himne beskryf. Hy was betrokke by die skepping. Alle geskape magte is aan Hom ondergeskik. Op grond van sy versoeningswerk aan die kruis het hy in-sondegevalle mense verlos van die oorheersing van alle magte. Hy oefen beheer uit oor alle kosmiese kragte. Christene hoef nie deur allerlei praktyke meer te probeer om die magte tevrede te stel en daardeur versoening met God te verkry nie. Christus het hulle volkome versoen. Hulle lewe het weer sin gekry.

Paulus vereenselwig hom met hierdie geloofsoortuiging van die vroeë kerk deur die formulering van 'n geloofsformule en die aanhaal van 'n himne. Hy verwag dat die lesers hulle ook daarmee sal vereenselwig. So word die grondslag gelê vir sy waarskuwings en etiese vermanings wat volg. Die mistastings kan op grond van die gemeenskaplike belydenis eenvoudig weerlê word. Belyers kan gebring word tot 'n beter verstaan van die Evangelie. Hierdie belydenis moet dan neerslag vind in die praktyk van hulle lewe.

Die strategiese manier waarop Paulus die himne in Kolossense gebruik, kan as voorbeeld dien vir die gebruik van liedere in die erediens vandag. 'n Lied het 'n sterk emotiewe en didaktiese funksie as dit liturgies gepas aangewend word. Met 'n lied kan 'n liturg soms meer bereik as met baie gepredikte woorde.

\section{Bibliografie}

BALCHIN, J.F. 1985. Col. 1:15-20. An early Christian hymn? The arguments from style. Vox Evangelica, 15:65-94.

BANDSTRA, A.J. 1974. Did the Colossian errorists need a mediator? (In Longenecker, R.N. \& Tenney, M.C., eds., New dimensions in New Testament study. Grand Rapids : Zondervan. p. 329-343.)

BAMMEL, E. 1961. Versuch zu Kol. 1:15-20. Zeitschrift für Neuentestamentliche Wissenschaft, 52:88-95.

BARKHUIZEN, J.H. 1985. Carmen Christianum: Inleiding tot die Grieks-Christelike himnografie van die eerste ses eeue. Pretoria: NG Kerkboekhandel.

BOTHA, J. 1989. Die Kolossense-himne (Kol. 1:15-20). (In Barkhuizen, J.H., red. Hymni Christiani. Pretoria : Hervormde Teologiese Studies. p. 54-82. (HTS Supplementum 1.)

CONZELMANN, H. 1955. Was glaubte die frühe Christenheit? Schweizerische Theologish Umsschau 25:61-74. (In Conzelmann, H. Theologie als Schriftauslegung: Aufsätze zum Neuen Testament. München : Kaiser. p. 106-119.) 
DU TOIT. A.B. 1984. Oriënterende opmerkings oor die Pauliniese briefliteratuur. (In Du Toit A.B., red. Handleiding by die Nuwe Testament. Band V. Pretoria : NG Kerkboekhandel. p. 1-22.)

HAHN, F. 1980. Bekenntnisformeln im Neuen Testament, in Unterwegs zur Einheit: Festschrift für Heinrich Stirnimann. Freiburg : Vandenhoeck.

HARVEY, J.D. 1998. Listening to the text, oral patterning in Paul's letters. Grand Rapids : Baker Books.

HELYER, L.L. 1994. Cosmic Christology and Colossians 1:15-20. Journal of the Evangelical Theological Society, 37(2):235-246.

HENDRIKSEN, W. 1962. Commentary on the Epistle to the Colossians. Edinburgh : Banner of Truth.

KÄSEMANN, E. 1965. Eine urchristliche Taufliturgie, in exegetische Versuche und Besinnungen, 34-50. Göttingen : Vandenhoeck.

KEHL, N. 1967. Der Christushymnus im Kolosserbrief: Eine motivgeschichtliche Untersuchung zu Kol. 1,12-20. Stuttgart : Katholisches Bibelwerk.

LAMP. J.S. 1998. Wisdom in Colossians 1:15-20: Contribution and significance. Journal of the Evangelical Theological Society, 41(1):45-53.

LIGHTFOOT, J.B. 1961 [1879]. Saint Paul's epistle to the Colossians and to Philemon with introduction, notes and dissertations. Revised edition. Grand Rapids : Zondervan.

LOHMEYER, E. 1964 [1930]. Die Briefe an die Kolosser und an Philemon. Göttingen : Vandenhoeck.

LOHSE, E. 1968. Die Briefe an die Kolosser und an Philemon. Göttingen : Vandenhoeck.

MALHERBE, A.J. 1988. Ancient epistolary theorists. Atlanta : Scolars Press.

MARTIN, R.P. 1972. Colossians: The Church's Lord and the Christian's liberty. Michigan : Zondervan.

MARTIN, R.P. 1983. New Testament hymns: Background and development. Expository Times, 94:132-136

McCOWN, W. 1979. The hymnic structure of Colossians 1:15-20. The Evangelical Quarterly, 51(3):156-162.

NORDEN, E. 1913. Agnostos Theos: Untersuchungen zur Formengeschichte Religiöser Rede. Stuttgart : Teubner.

O'BRIEN, P.Y. 1982. Colossians, Philemon. Waco : Word Books. (Word Biblical Commentary, 44.)

POKORNY, P. 1987. Die Brief des Pauls an die Kolosser. Berlin : Evangelische Verlaganstalt.

RIDDERBOS, J.H. 1960. Aan de Kolossenzen. Kampen : Kok.

ROBERTS, J.H. 1988a. Belydenisuitsprake as Pauliniese briefoorgange. Hervormde Teologiese Studies, 44(4):813-828.

ROBERTS, J.H. 1988b. Die bedreiging van die gemeente in Kolosse. Hervormde Teologiese Studies, 44(1):81-97.

ROBERTS, J.H. 1991. Bly by Christus die Hoof: Die Christologiese fundering van heilsbelewenis en lewenspraktyk. (In Roberts, J.H. et al., red. Teologie in konteks. Halfway House : Orion. p. 294-320.)

ROBERTS, J.H. 1997a. Die belydenisuitspraak Kolossense 1:13-20: Eenheid, struktuur en funksie. Hervormde Teologiese Studies, 53(3):476-497.

ROBERTS, J. 1997b. Verlos en vry. Halfway House : Orion.

SANDERS, J.T. 1971. The New Testament Christological Hymns: Their historical religious backgroud. Cambridge : University Press. 
SCHNIDER, F. \& STEGER, W. 1987. Studium zum neuentestamentliche Briefformular. Leiden : Brill.

SCHWEIZER, E. 1976. Die Brief an die Kolosser. Zürich : Benziger.

SNYMAN, A.H. 1989. Die Filippense-himne (Fil. 2:6-11). (In Barkhuizen, J.H., red. Hymni Christiani. Pretoria : Hervormde Teologiese Studies. p. 44-53.) (HTS Supplementum 1.)

STAUFFER, E. 1948. Die Theologie des Neuen Testaments. Guttersloh : Bertelsman.

SUMNEY, J. 1993. Those who pass judgement: The identity of the opponents in Colossians. Biblica, 74(3):366-388.

UITMAN, J.E. 1972. De Brief van Paulus aan de Colossenzen. Nijkerk : Callenbach.

VAN BROEKHOVEN, H. 1997. The social profiles in the Colossian debate. Journal for the Study of the New Testament, 66:73-90.

VERGEER, W.C. \& JANSE VAN RENSBURG, J.J. 1994. Die dwaalleer in Kolosse. 'n Konstruksie van die waarskynlike sosio-historiese en filosofiese konteks. In die Skriflig, 28(1):1-23.

VERGEER, W.C. 1995. Die dwaalleer in Kolosse (2): Die boodskap van die Kolossensebrief. In die Skriflig, 29(3):413-442.

VILJOEN, F.P. 1986. Die betekenis van "Thronoi, Kuriotetes, Archai" en "Eksousiai" in Kolossense 1:16. Potchefstroom : PU vir CHO. (MA-verhandeling.)

VILJOEN, F.P. 1990. Die betekenis van "psalmois, himnois" en "odais pneumatikais" in Kolossense 3:16 en Efesiërs 5:19. Potchefstroom : PU vir CHO. (Th.Dproefskrif.)

WOLTER, M. 1993. Der Brief an die Kolosser und der Brief an Philemon. Ökumenischer Taschenbuchkommentar zum Neuen Testament. Gutersloher Taschenbucher 519. Band 12. Gutersloh \& Wurzburg : Gutersloher Verlagshaus.

ZIMMERMANN, H. 1968. Neutestamentliche Methodenlehre: Darstellung der historisch-kritischen Methode. 2. Aufl. Stuttgart : Katholisches Bibelwerk.

\section{Kernbegrippe:}

belydenis

Christus-himne: Kolossense 1:13-20

Nuwe-Testamentiese himne

\section{Key concepts:}

Christ hymn: Colossians 1:13-20

creed

New Testament hymn 